\title{
KADAR PROTEIN, SERAT, TRIPTOFAN DAN MUTU ORGANOLEPTIK KUDAPAN EKSTRUSI JAGUNG DENGAN SUBSTITUSI KEDELAI
}

\author{
Bakhtiar Rudini, Fitriyono Ayustaningwarno \\ Program Studi Ilmu Gizi Fakultas Kedokteran Universitas Diponegoro \\ Jl.Dr.Sutomo No.18, Semarang, Telp (024) 8453708, Email : gizifk@undip.ac.id
}

\begin{abstract}
Background: snack consumption was increased, snack choice available usually low in nutritional quality such as too many fat, sugar and sodium. Extruded corn snack with soy substitution has great potential to be developed because it's contain high protein from soy, amino acids in corn and soybean are also complementary.

Objective: To analyze protein, fiber, tryptophan content and organoleptic quality of extruded corn snack with soy substitution.

Methods: An experimental research of completely randomized design with research subjects extruded corn snack with soy substitution in four substitution levels (0,25, 50, and 75\%), corn used was Pioneer II varieties and soybean from Lokon varieties. The analysis was protein content, fiber, tryptophan and organoleptic tests. Statistical analysis of protein content using One Way ANOVA test and fiber content using Kruskall-Wallis test, and the organoleptic quality using Friedman test.

Results: Highest protein content found in snack with $75 \%$ soy substitution $(28.014 \pm 1.192 \mathrm{~g} / 100 \mathrm{~g})$, the lowest protein content was snacks without substitution $(7.508 \pm 0.281 \mathrm{~g} / 100 \mathrm{~g})$. Highest fiber content found in snack with $75 \%$ soy substitution $(16.53 \pm 1.389 \mathrm{~g} / 100 \mathrm{~g})$, the lowest fiber content found in snack without substitution $(7.28 \pm$ $1.815 \mathrm{~g} / 100 \mathrm{~g})$. Highest content of tryptophan found in snack with $75 \%$ substitution $(156.8 \mathrm{mg} / 100 \mathrm{~g})$ and the lowest tryptophan content was snack without substitution $(99.6 \mathrm{mg} / 100 \mathrm{~g})$. Highest organoleptic quality was the snack without substitution, and the lowest was snack with $75 \%$ substitution. There were significant differences in protein and fiber content at all levels of substitution, protein and fiber content has increased in snacks with soy substitution. Organoleptic quality decreased with soy substitution, multiple comparisson tests showed significant differences between snack without substitution with substitution snack include taste, flavor and texture, while the color significantly difference at all levels of substitution.

Conclusion:The substitution of soybean to corn extruded snack could increase protein, fiber and tryptophan content, organoleptic test showed that snack without soy substitution most favored compared with snack with soy substitution, snack with soy substitution less accepted by panelists.
\end{abstract}

Keywords: soy and corn, protein, fiber, tryptophan, extrusion snack

\begin{abstract}
ABSTRAK
Latar Belakang : Konsumsi kudapan mengalami peningkatan, pilihan kudapan yang tersedia biasanya bersifat rendah dalam mutu gizinya seperti mengandung lemak, gula dan natrium yang berlebihan. Kudapan ekstrusi jagung dengan substitusi kedelai mempunyai potensi besar untuk dikembangkan karena selain kandungan protein kedelai yang cukup tinggi, asam amino pada jagung dan kedelai juga saling melengkapi.

Tujuan : Menganalisis kadar protein, serat, triptofan dan mutu organoleptik kudapan ekstrusi jagung dengan substitusi kedelai.

Metode : Merupakan penelitian eksperimental rancangan acak lengkap dengan subjek penelitian kudapan ekstrusi jagung dengan empat perlakuan substitusi kedelai (0, 25, 50, dan 75\%), jagung yang digunakan merupakan varietas Pioneer II dan kedelai yang digunakan adalah varietas Lokon. Analisis yang dilakukan adalah analisis kadar protein, serat, triptofan dan uji organoleptik. Uji statistik dari kadar protein menggunakan uji One Way ANOVA dan kadar serat menggunakan uji Kruskall-wallis, sedangkan mutu organoleptik menggunakan uji Friedman.

Hasil : Kadar protein tertinggi terdapat pada kudapan dengan substitusi kedelai 75\% (28,014 $\pm 1,304 \mathrm{~g} / 100 \mathrm{~g})$, kadar protein terendah terdapat pada kudapan tanpa substitusi $(7,508 \pm 0,296 \mathrm{~g} / 100 \mathrm{~g})$. Kadar serat tertinggi terdapat pada kudapan dengan substitusi kedelai 75\% (16,53 $\pm 1,389 \mathrm{~g} / 100 \mathrm{~g})$, kadar serat terendah terdapat pada kudapan tanpa substitusi $(7,28 \pm 1,815 \mathrm{~g} / 100 \mathrm{~g})$. Kadar triptofan tertinggi terdapat pada kudapan dengan substitusi $75 \%(156,8 \mathrm{mg} / 100 \mathrm{~g})$ dan terendah pada kudapan tanpa substitusi (99,6 mg/lo0g). Mutu organoleptik tertinggi terdapat pada kudapan tanpa substitusi, sedangkan mutu organoleptik terendah terdapat pada kudapan dengan substitusi $75 \%$. Terdapat perbedaan yang bermakna pada pengukuran kadar protein dan kadar serat di seluruh tingkatan subtitusi, kadar protein dan serat meningkat pada kudapan dengan substitusi kedelai. Mutu organoleptik semakin menurun dengan adanya substitusi kedelai, uji lanjut menunjukkan perbedaan yang bermakna antara
\end{abstract}

${ }^{*}$ Penulis Penanggungjawab 
kudapan tanpa subtitusi dengan kudapan subtitusi meliputi aroma, rasa dan tekstur, sedangkan perbedaan warna bermakna pada seluruh tingkatan subtitusi.

Simpulan : Substitusi kedelai terhadap kudapan ekstrusi jagung dapat meningkatkan kadar protein, serat dan triptofan, hasil penilaian mutu organoleptik menunjukkan bahwa kudapan tanpa substitusi kedelai paling disukai dibanding dengan kudapan dengan substitusi, kudapan dengan substitusi kedelai kurang dapat diterima oleh panelis.

Kata kunci : kedelai dan jagung, protein, serat, triptofan, kudapan ekstrusi

\section{PENDAHULUAN}

Konsumsi

peningkatan, pilihan kudapan yang tersedia biasanya bersifat rendah dalam mutu gizinya dan tinggi energi seperti permen, keripik, kue-kue manis dan kudapan lain yang biasanya mengandung lemak, gula dan natrium yang berlebihan. ${ }^{1}$ Kudapan ekstrusi berpotensi untuk dikembangkan, teknologi ekstrusi menyediakan peluang untuk memproses bermacam - macam produk kudapan dengan mengubah bahan dan memproses bahan tersebut dalam mesin yang sama. $^{2,3}$

Bahan baku yang paling sering digunakan adalah jagung (Zea mays), sejarah pengolahan dan produksi kudapan ekstrusi berawal dengan menggunakan bahan baku jagung karena kandungan amilosa dan amilopektin yang tinggi pada jagung (15g/100g dan 45g/100g) menyebabkan hasil akhir produk yang mengembang dan renyah. ${ }^{4,5}$ Sebagai bahan pangan, jagung adalah sumber karbohidrat dan protein. Kandungan protein jagung umumnya berkisar antara 8-11\%, namun kandungan asam amino triptofannya rendah, yaitu $50 \mathrm{mg} / 100 \mathrm{~g}$ sehingga masih kurang dari separuh yang disarankan oleh Food and Agriculture Organization. ${ }^{6}$ Bila dicampur dengan kacang kedelai, maka kekurangan lisin dan triptofan pada biji jagung akan tercukupi, begitu pula sebaliknya, biji jagung mengandung asam amino metionin yang lebih tinggi dari pada kedelai. Pada kondisi seperti ini, yang akan terjadi adalah efek komplementer protein, karena itu kedelai dapat digunakan untuk melengkapi kandungan gizi dari jagung. ${ }^{7-9}$

Kacang kedelai dapat menyumbang banyak protein dan zat gizi lain bagi masyarakat di negara maju dan negara berkembang. Kandungan serat kedelai cukup tinggi $(16 \mathrm{~g} / 100 \mathrm{~g})$, maka kedelai juga dapat dijadikan sebagai sumber serat. Penelitian mengenai efek kesehatan serat dari kacang-kacangan sebagian besar masih terbatas pada kacang kedelai. Dibandingkan dengan makanan berserat yang tersedia dalam bentuk makanan suplemen dengan berbagai merek dagang, sebenarnya kacang-kacangan juga dapat dijadikan sumber serat. Bahkan kacang-kacangan mempunyai keistimewaan lain, yaitu harga relatif murah, berprotein tinggi dan mengandung berbagai mineral dalam jumlah yang cukup banyak. ${ }^{10}$

Tingkat konsumsi serat penduduk Indonesia juga relatif rendah, yaitu 10,5 g/hari, dan rata-rata konsumsi serat penduduk Jawa Tengah $12,9 \mathrm{~g} /$ hari. Padahal, konsumsi serat dianjurkan karena komponen serat yang spesifik telah dilaporkan memiliki peran penting dalam pencegahan dan pengobatan beberapa gangguan gastrointestinal, kegemukan, aterosklerosis, jantung koroner, kanker kolon dan diabetes. Penambahan serat dalam kudapan merupakan cara alternatif untuk mencukupi kekurangan serat dari makanan utama. ${ }^{11}$

Berdasarkan uraian diatas, maka penelitian ini dilakukan untuk mengetahui adanya pengaruh substitusi kedelai pada kudapan ekstrusi jagung terhadap kadar protein, kadar serat, kadar triptofan dan mutu organoleptik kudapan.

\section{METODA}

Penelitian yang dilakukan ditinjau dari segi keilmuan termasuk dalam bidang Food Production, dilaksanakan mulai bulan Agustus 2010 hingga Februari 2011 di Laboratorium Teknologi Hasil Pertanian Fakultas Teknologi Hasil Pertanian Universitas Semarang, Laboratorium Gizi Fakultas Ilmu Kesehatan Universitas Muhammadiyah Semarang, Laboratorium Teknologi Pangan Fakultas Teknologi Pertanian Universitas Katolik Soegijapranata dan Laboratorium Kimia Fakultas Sains dan Matematika Universitas Kristen Satya Wacana.

Substitusi kedelai pada kudapan ekstrusi jagung merupakan penelitian eksperimental dengan 4 perlakuan substitusi (variabel bebas). Setiap perlakuan dilakukan 3 kali pengulangan dan setiap pengukuran dilakukan secara duplo. Untuk lebih jelasnya dapat dilihat di tabel 1 
Tabel 1. Presentase substitusi kedelai pada kudapan ekstrusi jagung

\begin{tabular}{ccccc}
\hline & \multicolumn{4}{c}{ Perlakuan } \\
\cline { 2 - 5 } Bahan & $\mathrm{A}$ & $\mathrm{B}$ & $\mathrm{C}$ & $\mathrm{D}$ \\
\hline Jagung & $100 \%$ & $75 \%$ & $50 \%$ & $25 \%$ \\
Kedelai & $0 \%$ & $25 \%$ & $50 \%$ & $75 \%$ \\
\hline
\end{tabular}

Kudapan ekstrusi jagung dengan substitusi kedelai adalah produk campuran antara jagung dan kedelai yang telah melalui proses penggilingan dan pencampuran sebelumnya. Jagung yang digunakan merupakan varietas Pioneer II, sedangkan kedelai yang digunakan merupakan varietas Lokon.

Data yang dikumpulkan pada penelitian yaitu kadar protein, kadar serat, kadar asam amino triptofan dan daya terima kudapan ekstrusi jagung dengan substitusi kedelai. Kadar protein pada kudapan ekstrusi jagung dengan substitusi kedelai diukur menggunakan metode Kjedahl, kadar serat menggunakan metode Gravimetri dan kadar asam amino triptofan menggunakan metode HPLC, sedangkan pengukuran mutu organoleptik kudapan dilakukan uji hedonik dengan panelis agak terlatih sebanyak 30 orang dari mahasiswa semester VI dan semester VIII Program Studi Ilmu Gizi Fakultas Kedokteran Universitas Diponegoro.

Pengaruh substitusi kedelai terhadap kadar protein kudapan diuji dengan One Way ANOVA dengan derajat kepercayaan $95 \%$ dan untuk mengetahui beda nyata antar perlakuan digunakan uji lanjut yaitu multiple comparation (Posthoc test) dengan uji LSD (Least Significant Different), pengaruh substitusi kedelai terhadap kadar serat kudapan diuji dengan Kruskal-Wallis dengan derajat kepercayaan $95 \%$ dan untuk mengetahui beda nyata antar perlakuan digunakan uji lanjut (Posthoc test) dengan uji Mann-Whitney, daya terima kudapan diuji dengan Friedman dengan derajat kepercayaan $95 \%$ dan untuk mengetahui beda nyata antar perlakuan digunakan uji lanjut Wilcoxon, pada kadar triptofan tidak dilakukan uji statistik dikarenakan pengulangan yang terbatas.

\section{HASIL}

Pada penelitian, peneliti mengukur kadar protein, kadar serat, kadar triptofan dan daya terima kudapan ektrusi jagung dengan penambahan kedelai.

\section{Kadar Protein}

Penambahan kedelai pada kudapan ekstrusi jagung menyebabkan peningkatan kadar protein, hal ini disebabkan karena kadar protein kedelai lebih tinggi dari kadar protein jagung. Hasil analisis kadar protein kudapan ekstrusi dapat dilihat pada lampiran 1 dan secara singkat dapat dilihat pada Tabel 2 .

Tabel 2. Rata-rata hasil analisis kadar protein kudapan

\begin{tabular}{cc}
\hline Substitusi & $\begin{array}{c}\text { Rata-rata protein } \\
(\mathrm{g} / 100 \mathrm{~g})\end{array}$ \\
\hline $0 \%$ & $7.508^{\mathrm{a}} \pm 0,281$ \\
$25 \%$ & $13.409^{\mathrm{b}} \pm 0,751$ \\
$50 \%$ & $20.009^{\mathrm{c}} \pm 2,389$ \\
$75 \%$ & $28.014^{\mathrm{d}} \pm 1,192$ \\
\hline
\end{tabular}

Keterangan : beda nyata antar perlakuan penambahan kedelai dalam satu kolom yang sama dinyatakan dengan huruf superscript yang berbeda.

Pada Tabel 2 dapat dilihat bahwa kadar protein tertinggi terdapat pada kudapan dengan substitusi kedelai $75 \%$ yaitu $28.014 \mathrm{~g} / 100 \mathrm{~g}$ dan kadar protein paling rendah adalah kudapan tanpa substitusi kedelai (0\%) yaitu $7.508 \mathrm{~g} / 100 \mathrm{~g}$. Semakin banyak kedelai yang ditambahkan, maka kadar protein pada kudapan cenderung meningkat.

\section{Kadar Serat}

Kadar serat semakin meningkat dengan adanya substitusi kedelai pada kudapan ekstrusi. Hasil analisis kadar serat kudapan ekstrusi dengan substitusi kedelai dapat dilihat pada lampiran 2 dan secara singkat dapat dilihat pada Tabel 3. 
Tabel 3. Rata-rata kadar serat kudapan

\begin{tabular}{cc}
\hline Substitusi & $\begin{array}{c}\text { Rata-rata kadar serat } \\
(\mathrm{g} / 100 \mathrm{~g})\end{array}$ \\
\hline $0 \%$ & $7,28^{\mathrm{a}} \pm 1,815$ \\
$25 \%$ & $9,68^{\mathrm{b}} \pm 0,426$ \\
$50 \%$ & $12,33^{\mathrm{c}} \pm 1,440$ \\
$75 \%$ & $16.53^{\mathrm{d}} \pm 1,389$ \\
\hline
\end{tabular}

Keterangan : beda nyata antar perlakuan penambahan kedelai dalam satu kolom yang sama dinyatakan dengan huruf superscript yang berbeda.

Tabel 3 menunjukkan bahwa substitusi kedelai menghasilkan kadar serat yang berbeda. Dapat dilihat bahwa kadar serat tertinggi terdapat pada kudapan dengan substitusi kedelai $75 \%$ yaitu $16,53 \mathrm{~g} / 100 \mathrm{~g}$ dan kadar serat paling rendah terdapat pada kudapan tanpa substitusi kedelai yaitu
$7,28 \mathrm{~g} / 100 \mathrm{~g}$. Substitusi yang meningkat menyebabkan kadar serat cenderung naik.

\section{Kadar Asam Amino Triptofan}

Pengukuran kadar asam amino triptofan hanya dilakukan satu kali pengulangan saja, dengan hasil yang dapat dilihat pada tabel 4 .

Tabel 4. Kadar triptofan kudapan

\begin{tabular}{cc}
\hline Substitusi & $\begin{array}{c}\text { Kadar triptofan } \\
(\mathrm{mg} / 100 \mathrm{~g})\end{array}$ \\
\hline $0 \%$ & 99,6 \\
$25 \%$ & 114,8 \\
$50 \%$ & 147,8 \\
$75 \%$ & 156,8 \\
\hline
\end{tabular}

Tabel 4 menunjukkan bahwa substitusi kedelai menghasilkan kadar triptofan yang berbeda. Dapat dilihat bahwa kadar triptofan tertinggi terdapat pada kudapan dengan substitusi kedelai $75 \%$ yaitu $156,8 \mathrm{mg} / 100 \mathrm{~g}$ dan kadar triptofan paling rendah terdapat pada kudapan dengan substitusi $0 \%$ yaitu 99,6 mg/100g. Substitusi yang meningkat menyebabkan kadar triptofan cenderung naik.

\section{Mutu Organoleptik}

Substitusi kedelai pada kudapan ekstrusi jagung berpengaruh terhadap warna, aroma, rasa dan tekstur. Hal ini terlihat semakin besar substitusi kedelai menunjukkan adanya warna, aroma, rasa dan tekstur yang berbeda. Nilai ratarata kesukaan panelis terhadap warna, aroma rasa dan tekstur kudapan dapat dilihat pada Tabel 5.

Tabel 5. Rata-rata tingkat kesukaan panelis terhadap warna, aroma, rasa dan tekstur kudapan ekstrusi jagung dengan substitusi kedelai.

\begin{tabular}{ccccc}
\hline Substitusi & Warna & Aroma & Rasa & Tekstur \\
\hline $0 \%$ & $3.2^{\mathrm{a}} \pm 0.714$ & $3.1^{\mathrm{a}} \pm 0.819$ & $2.7^{\mathrm{a}} \pm 1.028$ & $3.0^{\mathrm{a}} \pm 0.910$ \\
$25 \%$ & $2.6^{\mathrm{b}} \pm 0.809$ & $1.9^{\mathrm{b}} \pm 0.740$ & $1.8^{\mathrm{b}} \pm 0.699$ & $1.8^{\mathrm{b}} \pm 0.774$ \\
$50 \%$ & $2.1^{\mathrm{c}} \pm 0.615$ & $2.0^{\mathrm{b}} \pm 0.695$ & $1.8^{\mathrm{b}} \pm 0.819$ & $1.7^{\mathrm{b}} \pm 0.884$ \\
$75 \%$ & $1.3^{\mathrm{d}} \pm 0.521$ & $1.6^{\mathrm{c}} \pm 0.728$ & $1.6^{\mathrm{b}} \pm 0.770$ & $1.5^{\mathrm{b}} \pm 0.777$ \\
\hline
\end{tabular}

Keterangan : beda nyata antar perlakuan penambahan kedelai dalam satu kolom yang sama dinyatakan dengan huruf superscript yang berbeda.

Pada Tabel 5 menunjukkan bahwa penambahan kedelai dalam pembuatan kudapan berpengaruh pada rata-rata kesukaan panelis terhadap warna, aroma, rasa dan tekstur. Berdasarkan hasil penilaian panelis, kudapan yang paling disukai dari segi warna, aroma, rasa maupun tekstur adalah kudapan tanpa substitusi kedelai
$(0 \%)$, kemudian tingkat kesukaan terendah adalah kudapan dengan substitusi $75 \%$.

\section{PEMBAHASAN}

Kudapan ekstrusi jagung dengan substitusi kedelai ini merupakan salah satu produk yang diharapkan akan menjadi salah satu sumber kudapan yang mengandung protein, serat dan asam 
amino triptofan, sehingga bisa menjadi kudapan yang tinggi mutu gizinya. Uji kadar protein, uji kadar serat, uji kadar triptofan dan uji daya terima dilakukan untuk mengetahui kualitas kudapan yang dihasilkan.

\section{A. Kadar Protein dan Triptofan}

Substitusi kedelai mempengaruhi kadar protein pada kudapan dengan substitusi kedelai. Hal ini dapat dilihat dari kadar protein yang semakin meningkat dengan besarnya konsentrasi kedelai yang disubstitusikan. Peningkatan kadar protein dari kudapan dengan substitusi kedelai pun terlihat dari analisis secara statistik dengan hasil yang bermakna.

Protein merupakan suatu zat makanan yang sangat penting bagi tubuh, karena selain berfungsi sebagai bahan bakar dalam tubuh juga berfungsi sebagai zat pembangun dan zat pengatur seperti enzim. Protein merupakan satu-satunya sumber nitrogen bagi tubuh. ${ }^{9}$

Kedelai adalah sumber protein nabati yang paling tinggi, kedelai mengandung protein sebesar $40 \%$, sedangkan kandungan protein jagung berkisar antara $8-11 \%$. Protein nabati pada umumnya diketahui memiliki mutu yang lebih rendah jika dibandingkan dengan protein hewani, hal itu disebabkan karena protein nabati memiliki kandungan asam amino tertentu yang lebih rendah dari kebutuhan asam amino manusia. Biji-bijian seperti jagung cenderung rendah kandungan asam amino lisin dan triptofannya, sedangkan kacang kedelai cenderung rendah kandungan asam amino metionin. Penggabungan kedua sumber protein nabati tersebut merpakan usaha peningkatan jumlah dan mutu protein kudapan. ${ }^{7,12,13}$

Panas dan gesekan yang terjadi di dalam ekstruder menyebabkan terjadinya denaturasi protein. Denaturasi protein adalah perubahan konformasi struktur tersier dan kuartener. Denaturasi merupakan fenomena dimana terbentuk konformasi baru dari struktur yang telah ada. Denaturasi protein mengakibatkan turunnya kelarutan, hilangnya aktivitas biologi dan protein mudah dipecah oleh enzim proteolitik. ${ }^{14-15}$

Kecukupan protein didapatkan dengan menyesuaikan kebutuhan protein dari kudapan (10\% protein $\mathrm{AKG}$ ), dengan AKG 2000 kkal, kecukupan protein sebesar $15 \%$ didapatkan 75 gram protein, sehingga kecukupan protein dari kudapan didapatkan 7,5 gram protein per hari

Tabel 6. Kecukupan protein dari kudapan (10\% protein AKG)

\begin{tabular}{ccccc}
\hline $\begin{array}{c}\text { Kecukupan } \\
\text { protein } \\
\text { kudapan } \\
(\mathbf{g})\end{array}$ & \multicolumn{4}{c}{$\begin{array}{c}\text { kudapan/sajian (30g) } \\
(\mathbf{\%})\end{array}$} \\
\cline { 2 - 5 } & $\mathbf{0 \%}$ & $\mathbf{2 5 \%}$ & $\mathbf{5 0 \%}$ & $\mathbf{7 5 \%}$ \\
\hline 7.5 & 30 & 53.6 & 80 & 112.1 \\
\hline
\end{tabular}

Berdasarkan tabel 6, kudapan dengan substitusi kedelai $75 \%$ memiliki angka sumbangan tertinggi terhadap angka kecukupan gizi. Sedangkan kudapan tanpa substitusi memiliki presentase sumbangan protein terendah.

Protein merupakan polimer, dan bentuk monomernya adalah asam amino. Pada umumnya, protein terdiri dari 20 macam asam amino. Asam amino esensial merupakan asam amino yang tidak dapat disintesis dalam tubuh dan harus didapatkan dari makanan untuk menjaga keseimbangan nitrogen. Asam amino non-esensial dapat disintesis oleh tubuh jika jumlah nitrogen cukup tersedia. Triptofan merupakan salah satu asam amino esensial. ${ }^{16,17}$
Asam-asam amino yang sangat kurang dalam bahan makanan disebut asam amino pembatas. Asam amino dari suatu makanan yang dapat diserap oleh tubuh terbatas pada asam amino yang jumlahnya paling rendah. Pada jagung asam amino pembatasnya adalah triptofan, sedangkan pada kedelai asam amino pembatasnya adalah metionin. Bila dua jenis protein yang memiliki jenis asam amino esensial pembatas yang berbeda dikonsumsi bersama-sama, maka kekurangan asam amino dari satu protein dapat dicukupi oleh asam amino sejenis yang lebih tinggi pada protein lain. Dua protein tersebut saling mendukung sehingga mutu protein dari campuran kedua 
bahan tersebut menjadi lebih tinggi daripada salah satunya. ${ }^{9}$

Triptofan merupakan perkusor metabolis untuk banyak senyawa biokimia yang penting, seperti asam nikotinik, asam kinurenic, serotonin dan melatonin. Kandungan triptofan dalam beraneka macam bahan makanan sangatlah bervariasi. Di negara yang mengkonsumsi jagung sebagai sumber protein yang utama, sindrom kekurangan niasin dan pellagra sering ditemukan. Hal inilah yang menyebabkan pentingnya mengetahui kandungan triptofan dalam makanan. $^{16}$

Kecukupan triptofan didapatkan dengan menyesuaikan kebutuhan triptofan dari kudapan (10\% triptofan AKG), dengan triptofan AKG sebesar $180 \mathrm{mg}$, sehingga kecukupan triptofan dari snack didapatkan 18 mg triptofan per hari.

Tabel 7. Kecukupan triptofan dari kudapan (10\% total kebutuhan triptofan perhari)

\begin{tabular}{ccccc}
\hline $\begin{array}{c}\text { Kecukupan } \\
\text { triptofan } \\
\text { kudapan } \\
(\mathbf{m g})\end{array}$ & \multicolumn{4}{c}{$\begin{array}{c}\text { kudapan/sajian (30g) } \\
(\mathbf{\%})\end{array}$} \\
\cline { 2 - 5 } & $\mathbf{0 \%}$ & $\mathbf{2 5 \%}$ & $\mathbf{5 0 \%}$ & $\mathbf{7 5 \%}$ \\
\hline 18 & 165.5 & 191.1 & 246.3 & 261.3
\end{tabular}

Tabel 7 menunjukkan presentase sumbangan kudapan terhadap kebutuhan triptofan tertinggi pada kudapan dengan substitusi kedelai $75 \%$, sedangkan kudapan tanpa substitusi kedelai memiliki presentase sumbangan triptofan paling rendah.

\section{B. Kadar Serat}

Substitusi kedelai mempengaruhi kadar serat pada kudapan dengan substitusi kedelai. Hal ini dapat dilihat dari kadar serat yang semakin meningkat seiring dengan besarnya konsentrasi substitusi kedelai. Peningkatan kadar serat dari kudapan dengan substitusi kedelai dilihat dari analisis secara statistik dengan hasil yang bermakna.

Serat merupakan bagian struktural dari tanaman dan mereka ditemukan pada semua tanaman, sayuran, buah, serealia dan kacangkacangan. Sebagian besar serat merupakan polisakarida. Pati juga merupakan polisakarida, tetapi serat berbeda dengan pati dalam ikatan antar monosakaridanya, tidak dapat dipecah oleh enzim dalam tubuh. Oleh sebab itu, serat tidak menyumbang monosakarida, dengan kata lain menyumbangkan sedikit energi bahkan tidak sama sekali bagi tubuh. ${ }^{18,19}$

Kedelai telah diketahui sebagai sumber serat dari kacang-kacangan, kandungan seratnya sebesar $16 \mathrm{~g} / 100 \mathrm{~g}$ kedelai kering. Serat memiliki efek yang baik bagi kesehatan seperti, menurunkan indeks glikemi, menurunkan kadar kolesterol darah, mencegah obesitas, mencegah diabetes dan aterosklerosis. Selain itu, serat kedelai mempunyai keunggulan lain yaitu harganya yang relatif murah jika dibandingkan dengan buah maupun suplemen serat dalam berbagai merek..$^{10,20,21}$

Berdasarkan penelitian sebelumnya, diketahui bahwa proses ekstrusi tidak terlalu berpengaruh terhadap kandungan serat produk, kandungan serat produk kurang lebih sama seperti kandungan serat bahan penyusunya. ${ }^{15}$ Penelitian lain juga menyatakan bahwa tidak terdapat perbedaan struktur serat sebelum dan setelah proses ekstrusi. ${ }^{22}$ Serat yang diuji dalam penelitian ini adalah serat kasar (crude fiber), serat kasar merupakan bahan pangan yang tidak dapat terhidrolisis oleh bahan-bahan kimia yang digunakan untuk menganalisa serat kasar seperti $\mathrm{H}_{2} \mathrm{SO}_{4}$ dan $\mathrm{NaOH}$. Sedangkan serat pangan adalah bahan pangan yang tidak dapat dihidrolisis oleh enzim-enzim pencernaan. Nilai serat kasar lebih kecil daripada serat pangan, karena enzim-enzim pencernaan memiliki kemampuan menghidrolisis bahan pangan lebih rendah dibandingkan dengan asam sulfat dan natrium hidroksida. $^{23}$

Kecukupan serat didapatkan dengan menyesuaikan kebutuhan serat dari kudapan (10\% serat total kebutuhan serat perhari), dengan kebutuhan serat sebesar $30 \mathrm{~g}$, sehingga kecukupan serat dari kudapan didapatkan $3 \mathrm{~g}$ serat per hari. 
Tabel 8. Presentase Sumbangan Serat kudapan ekstrusi per hari

\begin{tabular}{ccccc}
\hline $\begin{array}{c}\text { Kecukupan } \\
\text { serat } \\
\text { kudapan } \\
(\mathbf{g})\end{array}$ & \multicolumn{4}{c}{$\begin{array}{c}\text { kudapan/sajian (30g) } \\
\text { (\%) }\end{array}$} \\
\cline { 2 - 5 } & $\mathbf{0 \%}$ & $\mathbf{2 5 \%}$ & $\mathbf{5 0 \%}$ & $\mathbf{7 5 \%}$ \\
\hline 3 & 72.6 & 96.6 & 123 & 165 \\
\hline
\end{tabular}

Tabel 8 menunjukkan presentase sumbangan kudapan terhadap kebutuhan serat tertinggi pada kudapan dengan substitusi kedelai 75\%, kudapan tanpa substitusi memiliki presentase sumbangan paling rendah.

\section{Mutu Organoleptik} Warna

Substitusi kedelai mempengaruhi nilai organoleptik terhadap warna pada kudapan dengan substitusi kedelai. Hal ini terlihat dari hasil penilaian oleh panelis terhadap warna. Hasil uji kesukaan terhadap warna kudapan menunjukkan bahwa kudapan yang paling disukai warnanya adalah kudapan tanpa substitusi kedelai.

Dilihat dari hasil produk dan uji tingkat kesukaan yang menunjukkan bahwa dengan perbedaan substitusi kedelai menghasilkan warna yang berbeda. kudapan tanpa substitusi kedelai yang dibuat menghasilkan warna kuning cerah, sedangkan kudapan dengan substitusi kedelai berwarna kuning kecoklatan hingga coklat muda.

Kudapan tanpa substitusi kedelai berwarna kuning cerah, ini disebabkan kandungan pigmen kuning-karoten didalam endosperm jagung, sedangkan kudapan dengan substitusi kedelai berwarna kuning kecoklatan hingga coklat muda. ${ }^{24}$

Dari hasil penelitian ini, bila dilihat dari warna kudapan dengan substitusi kedelai yang baik untuk digunakan adalah kudapan tanpa substitusi kedelai. Warna kudapan yang dihasilkan berwarna kuning cerah yang dapat diterima oleh panelis.

Aroma

Substitusi kedelai mempengaruhi nilai organoleptik terhadap aroma pada kudapan dengan substitusi kedelai. Hal ini terlihat dari hasil penilaian oleh panelis terhadap aroma. Hasil uji kesukaan terhadap aroma kudapan menunjukkan bahwa kudapan tanpa substitusi kedelai memiliki aroma yang paling disukai.

Dilihat dari hasil produk dan uji tingkat kesukaan yang menunjukkan bahwa dengan perbedaan substitusi kedelai menghasilkan aroma yang berbeda. kudapan dengan substitusi $0 \%$ yang dibuat menghasilkan aroma jagung, sedangkan kudapan dengan substitusi $25 \%, 50 \%$ dan $75 \%$ semakin beraroma kedelai atau langu, hal ini disebabkan oleh kandungan enzim lipoksigenase yang terkandung dalam kedelai. Waktu yang singkat selama proses ekstrusi belum cukup untuk menonaktifkan enzim ini secara keseluruhan. ${ }^{25}$

Kudapan tanpa substitusi kedelai beraroma jagung murni, ini disebabkan karena tidak ada substitusi kedelai sedangkan kudapan dengan substitusi kedelai beraroma agak langu.

Dari hasil penelitian ini, bila dilihat dari aroma kudapan dengan substitusi kedelai yang baik untuk digunakan adalah kudapan tanpa substitusi kedelai, aroma kudapan yang dihasilkan beraroma jagung yang disukai oleh panelis.

\section{Rasa}

Substitusi kedelai mempengaruhi nilai organoleptik terhadap rasa pada kudapan dengan substitusi kedelai. Hal ini terlihat dari hasil penilaian oleh panelis terhadap rasa. Hasil uji kesukaan terhadap rasa kudapan menunjukkan bahwa kudapan tanpa substitusi kedelai memiliki rasa yang paling disukai.

Dilihat dari hasil produk dan uji tingkat kesukaan, menunjukkan bahwa dengan penambahan kedelai menghasilkan rasa yang berbeda, tetapi berapapun presentase penambahan kedelai tidak berpengaruh terhadap perbedaan rasa. Hal ini terlihat dari uji kesukaan tidak menunjukkan perbedaan yang berarti pada substitusi $25 \%$, $50 \%$ dan $75 \%$. Kudapan dengan substitusi $0 \%$ menghasilkan rasa jagung yang khas, sedangkan pada kudapan dengan substitusi kedelai 25\%, 50\% dan 75\%, menghasilkan kudapan yang terasa kedelai.

Dari hasil penelitian, bila dilihat dari rasa kudapan dengan substitusi kedelai yang 
baik untuk digunakan adalah kudapan dengan substitusi kedelai dengan konsentrasi 0\%, karena rasa kudapan yang dihasilkan disukai oleh panelis.

\section{Tekstur}

Substitusi kedelai mempengaruhi nilai organoleptik terhadap tekstur kudapan dengan substitusi kedelai. Hal ini terlihat dari hasil penilaian oleh panelis terhadap tekstur. Hasil uji kesukaan terhadap tekstur kudapan menunjukkan bahwa kudapan yang paling disukai adalah kudapan tanpa substitusi kedelai.

Dilihat dari hasil produk dan uji tingkat kesukaan yang menunjukkan bahwa dengan perbedaan substitusi kedelai menghasilkan tekstur yang berbeda. Kudapan dengan substitusi $0 \%$ yang dibuat menghasilkan tekstur lunak/renyah, sedangkan kudapan dengan substitusi kedelai tekstur terasa agak keras hingga keras.

Kudapan tanpa substitusi kedelai bertekstur renyah karena kandungan amilosa dan amilopektin jagung yang tinggi, masingmasing $15 \%$ dan $45 \%$ dari keseluruhan pati jagung, semakin besar substitusi kedelai maka semakin kecil kandungan amilosa dan amilopektin kudapan.

Tekstur yang keras juga dipengaruhi oleh kandungan minyak yang cukup tinggi pada kedelai. Kandungan asam lemak dapat menghambat pengembangan produk selama proses ekstrusi, lemak akan membentuk suatu lapisan pada bagian luar granula pati. ${ }^{13}$

Dari hasil penelitian ini, bila dilihat dari tekstur kudapan dengan substitusi kedelai yang baik untuk digunakan adalah kudapan tanpa substitusi kedelai. Tekstur kudapan yang dihasilkan renyah yang disukai oleh panelis.

Penentuan formula yang direkomendasikan pada pembuatan kudapan ekstrusi jagung dengan substitusi kedelai

Penentuan

formula

yang

direkomendasikan dilakukan dengan mengamati perubahan komposisi kudapan yang meliputi : kadar protein, kadar serat, kadar triptofan serta mutu organoleptik. Semakin besar subtitusi kedelai, semakin meningkatkan nilai gizi kudapan, namun mutu organoleptik semakin menurun yang terlihat dari tekstur, rasa, warna dan aroma yang kurang disukai oleh panelis. Berdasarkan penelitian, formula terbaik terdapat pada kudapan dengan substitusi $50 \%$, hal ini disebabkan karena kandungan protein dan serat yang berbeda secara bermakna dan kandungan triptofan yang meningkat jika dibandingkan dengan kudapan yang disubstitusi kedelai 25\%, namun mutu organoleptiknya tidak berbeda secara bermakna pada aroma, rasa dan tekstur kudapan. Kandungan protein kudapan substitusi 50\% sebesar 20,009 \pm 2,389 g/100g, kandungan seratnya sebesar 12,33 \pm $1,44 \mathrm{~g} / 100 \mathrm{~g}$ serta kandungan triptofan sebesar $147,8 \mathrm{mg} / 100 \mathrm{~g}$, kudapan dengan substitusi $50 \%$ belum dapat diterima oleh panelis terlihat dari nilai organoleptik kudapan dari segi warna $(2,1$;agak suka), aroma (2,0; agak suka), rasa (1,8; tidak suka) dan tekstur (1,7; tidak suka).

\section{SIMPULAN DAN SARAN \\ Simpulan}

- Substitusi kedelai terhadap kudapan ekstrusi jagung dapat meningkatkan kadar protein, serat dan triptofan.

- Hasil penilaian mutu organoleptik menunjukkan bahwa kudapan tanpa substitusi kedelai paling disukai dibanding dengan kudapan dengan substitusi, kudapan dengan substitusi kedelai kurang dapat diterima oleh panelis.

Saran

- Perlu dilakukan penelitian lanjutan untuk mengetahui daya cerna protein secara in vitro maupun in vivo

- Formula yang direkomendasikan adalah kudapan dengan subtitusi 50\%, kandungan gizinya berbeda secara bermakna dibandingkan dengan kudapan subtitusi $25 \%$ namun mutu organoleptiknya tidak berbeda secara bermakna pada aroma, rasa dan tekstur kudapan.

\section{UCAPAN TERIMA KASIH}

Pertama-tama, terima kasih penulis haturkan pada Allah SWT yang telah memberi kemudahan dalam segala hal sehingga penulis dapat menyelesaikan artikel ini, kepada bapak Fitriyono Ayustaningwarno, STP, M.Si sebagai dosen pembimbing yang telah meluangkan waktu dan dengan sabar memberikan masukan dalam penulisan karya tulis ini, kepada Prof. dr. HM. Sulchan, M.Sc, DA. Nutr., SpGK dan Ibu Ninik Rustanti, STP, M.Si selaku dosen penguji atas kritik dan saran yang membangun untuk karya tulis ini, kepada pihak Universitas Muhammadiyah Semarang khususnya Laboratorium Ilmu Teknologi Pangan dan Laboratorium Kimia 
Makanan Jurusan D III Gizi atas bantuannya selama penelitian, kepada penanggung jawab perpustakaan Program Studi Ilmu Gizi atas pinjaman literaturnya, kepada keluarga penulis atas do'a dan dukungannya, kepada teman-teman atas bantuan doa dan motivasi.

\section{DAFTAR PUSTAKA}

1. Anderson J, Patterson K. Snack Foods: Comparing Nutrition Values Of Excellent Choices And "Junk Foods". Journal of the American College of Nutrition.2005; Vol. 24 :155-157.

2. Mian N Riaz. New technological solutions extrusion process. MPOC International Palm Oil Trade and Seminar; Kuala Lumpur. Malaysia. 2006 November $21-24$

3. Mian N Riaz, editor. Extruder In Food Applications. USA. 2000

4. Guy R, editor. Extrusion cooking technologies and applications. England: CRC; 2000.

5. Adil B Ahza. kumpulan makalah pelatihan "Teknologi Ekstrusi, Penggorengan dan Pemanggangan (bakery)". Pusat studi pangan dan gizi. Bekasi: 1996.

6. M Azrai, MJ Mejaya, M Yasin HG. Pemuliaan Jagung Khusus. Balai Penelitian Tanaman Serealia. 2006; 96-98.

7. Ambarwani, Joko Susilo. Pengaruh Penambahan Biji Wijen (Sesamum Indicum) dan Kecambah Jagung (Zea Mays) Terhadap Kadar Protein Susu Kedelai. Jurnal Penelitian Sains \& Teknologi, 2004: Vol. 5, No. 1, 141-149.

8. Andi Wijaya, Resa Fasti, Farida Zulvica. Efek Xenia Pada Persilangan Jagung Surya Dengan Jagung Srikandi Putih Terhadap Karakter Biji Jagung. Jurnal Akta Agrosia Edisi Khusus. 2007. No. $2199-203$.

9. FG Winarno. Kimia Pangan dan Gizi. Jakarta: Gramedia; 2004

10. Sutrisno Koswara. Kacang - kacangan Sumber Serat yang Kaya Gizi. [cited 2010 Juli 28]. Available from : URL: HYPERLINK http : //www.Ebookpangan.com/

11. Jahari AB, Sumarmo I. Epidemiologi Konsumsi Serat di Indonesia. Majalah Gizi Indonesia. 2001; 25: 37-56

12. Murano PS. Understanding Food Science and Technology. USA: Wadsworth.2003; p.32-33

13. Messina MJ. Legumes And Soybeans: Overview of Their Nutritional Profiles And Health Effects. USA: Am J Clin Nutr 1999;70(suppl):439S-450S.

14. Devi Ambarwaty Oktavia. Kajian SNI Makanan Ringan Ekstrudat. Jurnal Standarisasi. 2007: vol 9(1); 1-9

15. NS Palupi, FR Zakaria dan E Prangdimurti. Pengaruh Pengolahan Terhadap Nilai Gizi Pangan. Modul e-Learning ENBP, Departemen Ilmu \& Teknologi Pangan-Fateta-IPB.2007
16. Nollet LML. HPLC. New York: Marcell Dekker; 2000

17. Belitz HD, Grosch W, Schieberle P. Food Chemistry, 4th Revised and Extended Editor. Berlin : Springer-Verlag Berlin Heidelberg; 2009.

18. Rolfes SR, Pinna K, Whitney E. Understanding Normal and Clinical Nutrition $7^{\text {th }}$ edition. USA: Wadsworth; 2006

19. Whitney WN, Rolfes SR. Undesstanding Nutrition. $9^{\text {th }}$ edition. USA: Wadsworth; 2002. p.98-101,403-9

20. Deddy Muchtadi. Sayuran Sebagai Sumber Serat Pangan Untuk Mencegah Timbulnya Penyakit Degeneratif. Jurnal Teknologi dan Industri Pangan, VoL XII, No.1. IPB; 2001

21. Blair RM, Henley EC, Tabor A. Soy Foods Have Low Glycemic And Insulin Response Indices In Normal Weight Subjects. Nutrition Journal; 2006; $5: 35$

22. Shahidi F, Ho Chi-Tang, Chuyen NV, editors. Process Induced Chemical Changes in Food. USA: Plenum Publishing; 1998

23. Tensiska. Serat Makanan [skripsi]. Jurusan Teknologi Industri Pangan Fakultas Teknologi Industri Pertanian: Universitas Padjadjaran; 2008.

24. Scott CE, Eldridge AL. Comparison Of Carotenoid Content In Fresh, Frozenand Canned Corn. Journal of Food Composition and Analysis 18; 2005; 551 559

25. Junghans TG, Oliveira MGA, Moreira MA. Lipoxygenase activities during development of root and nodule of soybean. Brasília: Pesq. agropec. bras.; 2004; p.625-630 